\title{
Hazard Analysis Critical Control Points (HACCP) Principle 5: Establish Corrective Actions 1
}

Ronald H. Schmidt and Debby Newslow ${ }^{2}$

Under a properly implemented HACCP System, whenever a deviation from a critical limit (CL) for a critical control point (CCP) occurs, there shall be a corrective action. A deviation is a failure to meet a CL. It indicates that a possible food safety hazard may have occurred and that unsafe product may have been produced. Thus, corrective actions must be immediate and must trigger an automatic review of the HACCP plan.

Corrective actions and expected actions or outcomes, as defined by different agencies and organizations, are presented in Table 1.

The HACCP team should routinely pay close attention to operational trends. This should include tracking the frequency of the process adjustments that are required when operating limits are exceeded. A pattern of exceeding operating limits on a regular basis could serve as a warning that a deviation may be imminent.

\section{Properties of Corrective Actions}

- Specific: Corrective actions are required for each affected CCP, and for each and every deviation at each CCP.
- Immediate and comprehensive: The time for corrective action is dependent upon the monitoring frequency. All food products affected and produced within the monitoring time period must be brought under control. Holding and storage provisions for pending product must be included.

- Documented: Every corrective action for every deviation must be recorded on an appropriate form.

\section{Corrective Action Plan}

A written Corrective Action Plan is required, and each corrective action must be documented.

Corrective actions are specific for each hazard and for each CCP. The plan must provide for immediate corrective actions. However, time factors will vary with monitoring procedures. It is important to note that, when a deviation occurs, a corrective action must be taken on all affected food products produced since the last monitoring observation or measurement. Thus, provisions in a corrective action plan should include procedures for holding suspected product as appropriate.

1. This document is FSHN 07-06, one of a series of the Department of Food Science and Human Nutrition, Florida Cooperative Extension Service, IFAS, University of Florida. First published July 2007. Please visit the EDIS Web site at http://edis.ifas.ufl.edu.

2. Ronald H. Schmidt, professor, Food Science and Human Nutrition Department, Cooperative Extension Service, Institute of Food and Agricultural Sciences, University of Florida, Gainesville FL 32611, and Debby Newslow, Executive Director, D.L. Newslow and Associates, Inc.

The Institute of Food and Agricultural Sciences (IFAS) is an Equal Opportunity Institution authorized to provide research, educational information and other services only to individuals and institutions that function with non-discrimination with respect to race, creed, color, religion, age, disability, sex, sexual orientation, marital status, national origin, political opinions or affiliations. U.S. Department of Agriculture, Cooperative Extension Service, University of Florida, IFAS, Florida A. \& M. University Cooperative Extension Program, and Boards of County Commissioners Cooperating. Larry Arrington, Dean 
The goals of a Corrective Action Plan are to:

- Establish a system that allows and promotes rapid response to deviations from a critical limit;

- Correct and eliminate the cause of the deviation and restore process control;

- Maintain accurate documentation and records; and

- Identify affected product and determine appropriate disposition.

\section{Corrective Action Procedures}

The typical sequence of events involved in a Corrective Action are as follows:

- Step 1: Stop the line or process, and segregate affected product.

- Step 2: Adjust process to bring the CCP back under control and correct the cause of the deviation.

- Step 3: Document and record the action(s) taken.

- Step 4: Consult with the HACCP team (and any others deemed appropriate).

- Step 5: Inform regulatory officials, if appropriate (required under USDA/FSIS).

- Step 6: Follow product disposition plan and/or conduct a product disposition analysis.

- Step 7: Determine whether modification of the HACCP plan is necessary.

\section{A. Segregation of Food Product(s)}

As described above, a deviation and subsequent corrective action indicates the possibility that unsafe products have been produced since the last monitoring. Therefore, all of the food produced within that monitoring period must be segregated and held until its safety has been determined.

\section{B. Process Adjustments}

To avoid future deviations, it is important that, during a corrective action on a CCP, the process be adjusted to restore control. Adjusting the process may involve activities such as adjusting the temperature, adjusting and recalibrating instruments (e.g. metal detectors), and manual adjustment (e.g., adjusting $\mathrm{pH}$ in brines, increasing sanitizer strength). It is recommended that written, defined procedures be used. Further, the need for adjustments may result in reevaluation of verification activities, such as calibration.

\section{Documentation of Corrective Actions}

Documentation and records of all corrective actions for all CCPs must be maintained on appropriate forms. In addition, corrective actions should be summarized in a narrative statement. These records should demonstrate both corrective actions and product disposition. In addition, they assist in assessing recurring problems and the need for modifications.

At a minimum, corrective action records must include:

- Product identification: description, code and/or lot number, hold number, amount of hold;

- Description of deviation;

- Date of occurrence;

- Corrective action taken and process adjustments;

- Name of responsible individual; and

- Results of product evaluation and disposition.

Improper corrective actions, or lack of corrective actions when deviations occur, are a major cause of regulatory violation of HACCP plans for those commodities under federal regulation. Therefore, where appropriate, the HACCP team should consult regulatory requirements. At the bare minimum, corrective actions must be summarized on the HACCP Plan Summary Form, as shown in Table 2. In addition, corrective actions should be described in more detail in a Corrective Action Log (Table 3). 


\section{Product Disposition Analysis}

The typical steps involved with a Product Disposition Analysis are as follows:

- Step 1. Determine if the product presents a safety hazard. This may involve expert evaluation of product sampling and testing.

- Step 2. If no hazard exists, either release product "as is," or downgrade and release.

- Step 3. If a potential hazard exists, determine whether the product can be reworked (e.g., recooked, repackaged, reconditioned) or diverted for an alternative safe use (e.g., used for animal feed, or denatured for rendering),

- Step 4. If the product cannot be handled as described above, it must be destroyed, following appropriate destruction procedures that do not impact the environment.

\section{Summary}

Corrective actions are key to preventing the sale of unsafe product. Corrective actions shall be taken for every deviation from a Critical Limit. The cause of the deviation shall be corrected and any modifications made to prevent recurrence. It is imperative that these actions be taken, that they be thorough, and that they be documented.

\section{References}

Codex Alimentarius. (2003). Hazard analysis and critical control point (HACCP) system and guidelines for its application. ANNEX to Recommended International Code of Practice/General Principles of Food Hygiene. CAC/RCP 1-1969, Rev 4. FAO/WHO Codex Alimentarius Commission.

National Advisory Committee on Microbiological Criteria for Foods (NACMCF). (1998). Hazard analysis and critical control point principles and application guidelines. Journal of Food Protection, 61, 762.

Food and Drug Administration Center for Food Safety and Applied Nutrition. (1995). Procedures for the safety and sanitary processing and importing of fish and fishery products. Final Rule, 18 Dec. 1995. Federal Register, 60, 65095-65202.

Food and Drug Administration Center for Food Safety and Applied Nutrition. (1995). Fish and fishery products. Code of Federal Regulations, Title 21, Part 123.

Food and Drug Administration Center for Food Safety and Applied Nutrition. (2001). Hazard analysis and critical control point (HAACP) (sic) procedures for the safe and sanitary processing and importing of juice. Final Rule, 19 Jan. 2001. Federal Register, 66, 6137-6202.

Food and Drug Administration Center for Food Safety and Applied Nutrition. (2001). Hazard analysis and critical control point (HACCP) systems. Code of Federal Regulations, Title 21, Part 120.

Food Safety and Inspection Service. (1996). Pathogen reduction; hazard analysis and critical control point (HACCP) systems. Final Rule, 25 July 1996. Federal Register, 61, 38856-38906.

Food Safety and Inspection Service. (1996). Hazard analysis and critical control point (HACCP) systems. Code of Federal Regulations, Title 9, Part 417.

Scott, V. N., and Stevenson, K. E. (2006). HACCP: A systematic approach to food safety. Washington, D.C.: Food Products Association.

Schmidt, R. H., and Newslow, D. L. (2007). Hazard analysis critical control points (HACCP) Getting started, preliminary steps (FSHN0701). Gainesville: Department of Food Science and Human Nutrition, Florida Cooperative Extension Service, Institute of Food and Agricultural Sciences, University of Florida. Retrieved July 24, 2007, from http://edis.ifas.ufl.edu/FS137

Schmidt, R. H., and Newslow, D. L. (2007). Hazard analysis critical control points (HACCP) Prerequisite programs (FSHN0702). Gainesville: Department of Food Science and Human Nutrition, Florida Cooperative Extension Service, Institute of Food and Agricultural Sciences, University of 
Florida. Retrieved July 24, 2007, from

http://edis.ifas.ufl.edu/FS138

Schmidt, R. H., and Newslow, D. L. (2007).

Hazard analysis critical control points (HACCP) -

Principle 1: Conduct a Hazard Analysis

(FSHN0703). Gainesville: Department of Food

Science and Human Nutrition, Florida Cooperative

Extension Service, Institute of Food and Agricultural

Sciences, University of Florida. Retrieved August 10,

2007, from http://edis.ifas.ufl.edu/FS139

Schmidt, R. H., and Newslow, D. L. (2007).

Hazard analysis critical control points (HACCP) -

Principle 2: Determine Critical Control Points

(CCPs) (FSHN0704). Department of Food Science

and Human Nutrition, Florida Cooperative Extension

Service, Institute of Food and Agricultural Sciences,

University of Florida. Retrieved August 10, 2007,

from http://edis.ifas.ufl.edu/FS140

Schmidt, R. H., and Newslow, D. L. (2007).

Hazard analysis critical control points (HACCP) -

Principle 3: Establish Critical Limits and Principle

4: Monitoring Critical Control Points (CCPs)

(FSHN0705). Gainesville: Department of Food

Science and Human Nutrition, Florida Cooperative

Extension Service, Institute of Food and Agricultural

Sciences, University of Florida. Retrieved August 15, 2007, from http://edis.ifas.ufl.edu/FS141 
Table 1. Definitions for Corrective Actions and Expected Outcomes

\begin{tabular}{|c|c|c|}
\hline Agency or Organization & Definition of Corrective Actions & Expected Outcome \\
\hline $\begin{array}{l}\text { National Advisory Committee on } \\
\text { Microbiological Criteria for Foods } \\
\text { (NACMCF) }\end{array}$ & $\begin{array}{l}\text { Procedures followed when a deviation } \\
\text { occurs. }\end{array}$ & $\begin{array}{l}\text { - Determine and correct the cause of } \\
\text { non-compliance; } \\
\text { - Determine the disposition of } \\
\text { product; } \\
\text { - Record the corrective action that } \\
\text { has been taken; } \\
\text { - Specify who is responsible for the } \\
\text { corrective action and for the } \\
\text { oversight. }\end{array}$ \\
\hline $\begin{array}{l}\text { Food and Drug Administration } \\
\text { (FDA) }\end{array}$ & $\begin{array}{l}\text { Whenever a deviation from a CL } \\
\text { occurs, a processor shall take } \\
\text { corrective actions. }\end{array}$ & $\begin{array}{l}\text { - Following a corrective action plan } \\
\text { that is appropriate for the } \\
\text { particular deviation, or } \\
\text { - When no plan exists, following } \\
\text { procedures set forth (under the } \\
\text { regulation). }\end{array}$ \\
\hline Codex Alimentarius & $\begin{array}{l}\text { Any action to be taken when the } \\
\text { results of monitoring at the CCP } \\
\text { indicate loss of control. }\end{array}$ & $\begin{array}{l}\text { - Must ensure that the CCP has } \\
\text { been brought under control. } \\
\text { - Must include proper disposition of } \\
\text { affected product. } \\
\text { - Must be documented. }\end{array}$ \\
\hline
\end{tabular}




\begin{tabular}{|c|c|}
\hline $\begin{array}{l}\frac{0}{0} \\
\frac{0}{\sqrt[N]{N}} \\
\text { N } \\
\text { T }\end{array}$ & 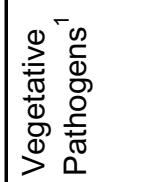 \\
\hline 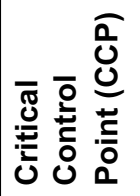 & 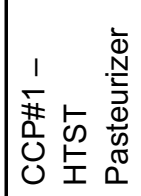 \\
\hline
\end{tabular}




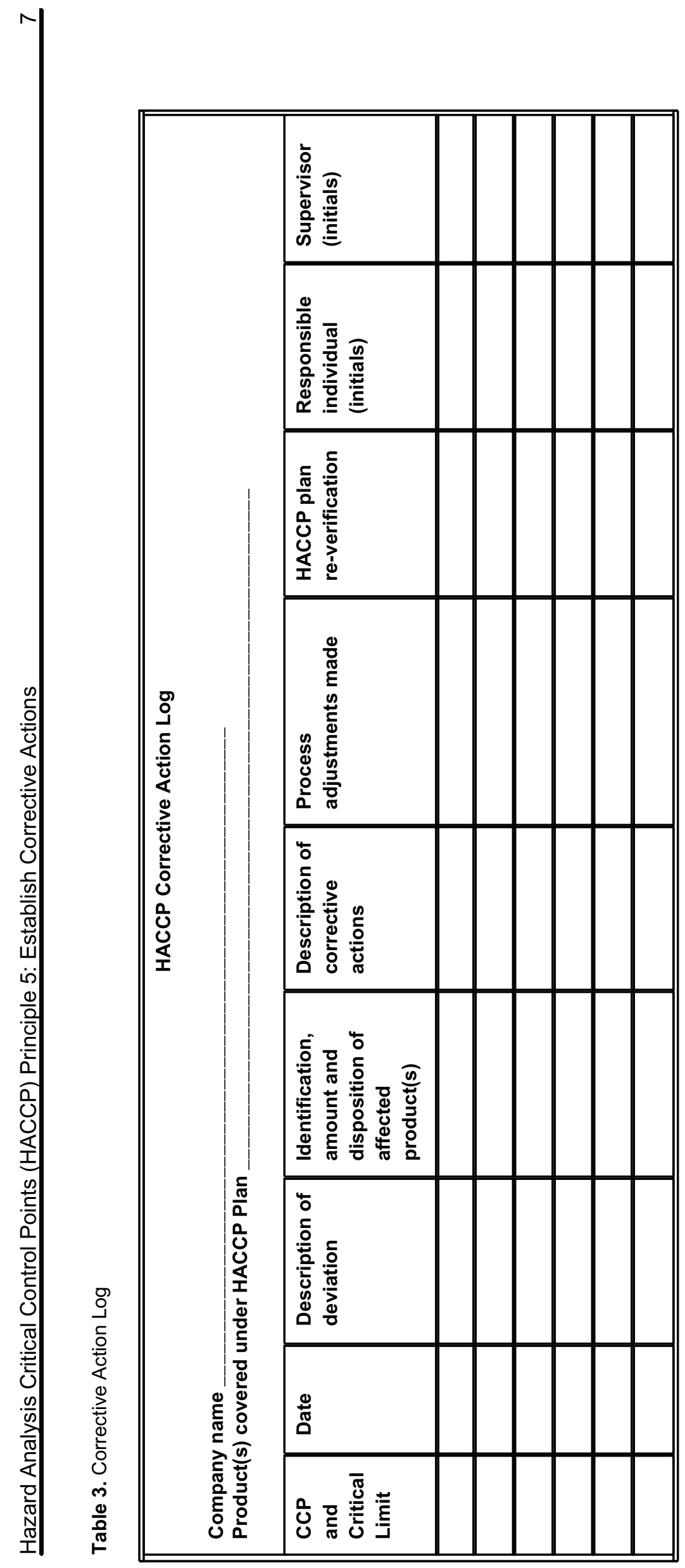

